\title{
Influence of Ionising Radiation on the Activity of Selected Adaptive Enzymes in Chickens and Rats
}

\author{
K. BEŇOVÁ ${ }^{1}$, M. TOROPILA ${ }^{1}$, M. FALIS ${ }^{1}$, P. DVOŘÁK ${ }^{2}$ \\ ${ }^{1}$ University of Veterinary Medicine, Košice, Slovak Republic, \\ ${ }^{2}$ Department of Biochemistry and Biophysics, \\ University of Veterinary and Pharmaceutical Sciences, Brno, Czech Republic \\ Received June 3, 2002 \\ Accepted November 18, 2003
}

\begin{abstract}
Beňová K., M. Toropila, M. Falis, P. Dvořák: Influence of Ionising Radiation on the Activity of Selected Adaptive Enzymes in Chickens and Rats. Acta Vet. Brno 2003, 72:201-205.

The effects of ionising radiation on the activity of two adaptive enzymes in the serum of poultry and laboratory rats were investigated. Chickens were divided into three groups. Those aged 28 days were gamma-irradiated with either a single whole-body dose of $2.0 \mathrm{~Gy}$ (output $0.27 \mathrm{~Gy} / \mathrm{min}$ ) (group 1, $\mathrm{n}=6$ ), or a single whole-body dose of $4.5 \mathrm{~Gy}$ (output $0.33 \mathrm{~Gy} / \mathrm{min}$ ) (group $2, \mathrm{n}=6$ ). Rats and chickens (group 3, $\mathrm{n}=6$ ) aged 37 days were exposed to a single whole-body dose of 5.0 Gy (output $0.27 \mathrm{~Gy} / \mathrm{min}$ ). Analyses were carried out at 6,24 and $48 \mathrm{~h}$ after irradiation.

Chickens irradiated with the 2.0 Gy dose showed a significant decrease in the activity of ALT at 6,24 and $48 \mathrm{~h}$ after irradiation compared to controls. Chickens irradiated with the $4.5 \mathrm{~Gy}$ and 5.0 Gy dose showed a significant decrease at 6 and $24 \mathrm{~h}$ after irradiation. Rats irradiated with the 5.0 Gy dose showed a significant decrease in the activity of ALT at 24 and $48 \mathrm{~h}$ after irradation compared to controls.

The activity of aspartate aminotransferase was increased in all observation periods in chickens from the group irradiated with $2.0 \mathrm{~Gy}$. The chickens irradiated with 4.5 Gy showed a decrease in this parameter, significant $(p<0.05)$ at 6 and $48 \mathrm{~h}$ after irradiation. The activity of AST in chickens irradiated with $5.0 \mathrm{~Gy}$ was increased in all periods of investigation. A non-significant decrease in the activity of AST was detected in rats irradiated with $5.0 \mathrm{~Gy}$ in all periods of observation compared to controls.

The results of this study show different effects of ionizing radiation on two adaptive enzymes, both in chickens and rats.
\end{abstract}

Gamma radiation, rat, chick, alanine aminotransferase, aspartate aminotransferase

There is no doubt that use of nuclear power is one of the important discoveries of the $20^{\text {th }}$ century. However, this discovery poses risks to humans and other living systems, whether in the form of nuclear weapons, increasing radioactive background, or accidents with technical equipment intended for peaceful use of nuclear energy. This indicates a need for continuous study of harmful effects of ionising radiation not only on mammals (Flory and Neuhaus 1976; Konečná and Kalina 1987; Maruyama and Feola 1987; Kalina et al.1994; Staníková et al. 1994; Cigánková et al. 1996) but also on other species (Sesztáková 1996; Škardová et al. 1994).

At the same time, new radioprotective substances are searched for and tested with the aim to decrease the radiation damage (Fe doročko et al. 1992, 1994).

Adaptation of organisms to changes in the external environment is achieved through a sequence of very closely related adaptive processes which result eventually in a new balance between an organism and its environment. With respect to this it is important that individual changes do not necessarily result from the original stimulus but they constitute most frequently a response to the changes in the preceding link of the adaptive chain.

Adaptation may be induced by prolonged continuous or intermittent stimuli. They may include, besides cell plasma-nucleus relations, also such regulatory mechanisms that 
affect the organism as a whole. Adaptation involves almost all physiological functions. However, their final impact is manifested on a cellular level. "The adaptive enzymes" such as ALT and AST are of importance for diagnosis of diseases. Their activities change under the influence of various effects of environment and therefore they are still the aim of research work.

Enzymes play one of paramount roles in metabolic processes of the body. They attracted considerable attention both under physiological conditions and after the action of some pathogenic factors (Kottferová et al. 2001), e.g. ionising radiation (Toropila et al. 1995). The character of changes in the activity of enzymatic systems, either in cells or in animal tissues, is important for elucidation and understanding of the effect of ionising radiation on biological material.

Thus a question comes to the fore, whether radiation damage to cells, tissues or organisms, accompanied by the damage to their function and destruction and disintegration of many biologically important substances, is not caused by the damage to these metabolic regulators (Ševčík ová et al. 2000).

The present study investigated changes in the serum activity of alanine aminotransferase and aspartate aminotransferase in laboratory rats and domestic fowl subjected to single, whole-body irradiation with gamma rays at doses of 2.0, 4.5 and 5 Gy.

\section{Materials and Methods}

The experiment was carried on 26 chickens - broiler hybrids 37 -day-old ( 6 birds per each of three experimental groups, 8 birds in control group) and 45 chickens 28 -day-old ( 6 birds per each experimental groups, 9 birds in the same control group). After previous disinfection of experimental facilities the chickens were allowed to acclimatize to experimental conditions. They were fed a granulated BR II diet and water ad libitum. In the period of acclimatization, they were preventively administered an intestinal disinfectant in the form of Cholesol tablets a.u.v., at a dose of 1 tablet per litre of water per day.

The second experiment was conducted with laboratory female rats of Wistar SPF breed, obtained from the breeding station VELAZ Prague, CR. Their initial mean body weight was $180 \mathrm{~g}$. The experimental facilities were disinfected and the rats were kept for one week before the experiment in plexit cages on wooden shavings at $22-24^{\circ} \mathrm{C}$, relative humidity 60-70\%, and natural illumination (Ondrašovič et al. 1997) to adapt to the experimental conditions. They had free access to pellets of LD diet and water (Toropila et al. 1996).

The animals were irradiated directly in adjusted plexit cages out at the Faculty of Natural Sciences of UPJŠ in Košice, using the CHISOSTAT ${ }^{60} \mathrm{Co}$-Chirana apparatus. Chickens were divided into 3 groups according to the dose. At the beginning of the experiment the first group of chickens, 28-day-old, was irradiated with a single whole-body dose of gamma rays of $2.0 \mathrm{~Gy}$, at the output of $0.27 \mathrm{~Gy} / \mathrm{min}$. The second group of 28 -day-old chickens was irradiated with a single whole body dose of $4.5 \mathrm{~Gy}$, at the output of $0.27 \mathrm{~Gy} / \mathrm{min}$. The rats and 37-day-old chickens were exposed to a single whole-body irradiation at a dose of $5.0 \mathrm{~Gy}$ of gamma rays and the output of $0.27 \mathrm{~Gy} / \mathrm{min}$.

Sham irradiation of the controls was carried out in parallel, i.e. the animals were exposed to the same treatments as the experimental ones except for the irradiation with gamma rays. Analyses were carried out at 6,24 and $48 \mathrm{~h}$ post-irradiation. The animals were decapitated after an overnight fast (Bugarský et al. 1995). The mixed blood and lymph were collected in Petri dishes, centrifuged, and the serum obtained was used for determination of AST and ALT activities by means of Bio-la-test kits (Lachema-Brno). Measurements were carried out on a spectrophotometer Spekol 11. Statistical significance of differences between experimental groups and control (not irradiated) was determined by the unpaired $t$-test.

\section{Results}

The activity of alanine aminotransferase (Fig. 1) decreased in all experimental groups and periods of observation compared to controls. The difference was significant $(p<0.05)$ in chickens irradiated with a dose of $2.0 \mathrm{~Gy}$ in all periods of observation. The chickens exposed to doses of 4.5 and 5.0 Gy exhibited a significant decrease $(p<0.05)$ after 6 and 24 h. The rats exposed to a dose of 5.0 Gy showed significantly decreased activity of ALT at 24 and $48 \mathrm{~h}$ post-irradiation in comparison with the control.

The activity of aspartate aminotransferase (Fig. 2) increased in all periods of observation in chickens exposed to the $2.0 \mathrm{~Gy}$ dose. The difference was significant $24 \mathrm{~h}$ post-irradiation. 
The chickens exposed to irradiation with 4.5 Gy had a decreased activity of AST. The difference was significant at 6 and $48 \mathrm{~h}$ post-irradiation. The chickens irradiated with 5.0 Gy showed an increased activity of AST in all experimental periods, significant at $6 \mathrm{~h}$ postirradiation. Activity of AST decreased, though nonsignificantly, compared to controls in all periods under study in rats exposed to the dose of $5.0 \mathrm{~Gy}$.

\section{Discussion}

After irradiation of live systems the enzyme activity may either decrease or increase contrary to irradiation of pure isolated enzymes which results in no such changes (Toropila 1993). The damage to enzymes in the irradiated organisms may occur in the active protein centre, in the prosthetic components of enzymes, or enzymatic bonds. The increased activity, particularly of the adaptive enzymes, points to predominance of catabolic processes in the irradiated

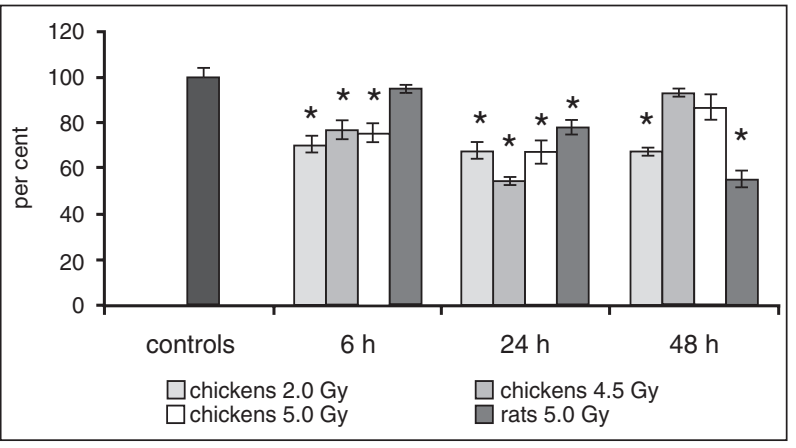

Fig. 1. Changes in the serum activity of ALT (\%) after single whole-body irradiation. significance of differences between irradiated and control groups is marked $*(p<0.05)$. The presented values are given against $100 \%$ level of the control values.

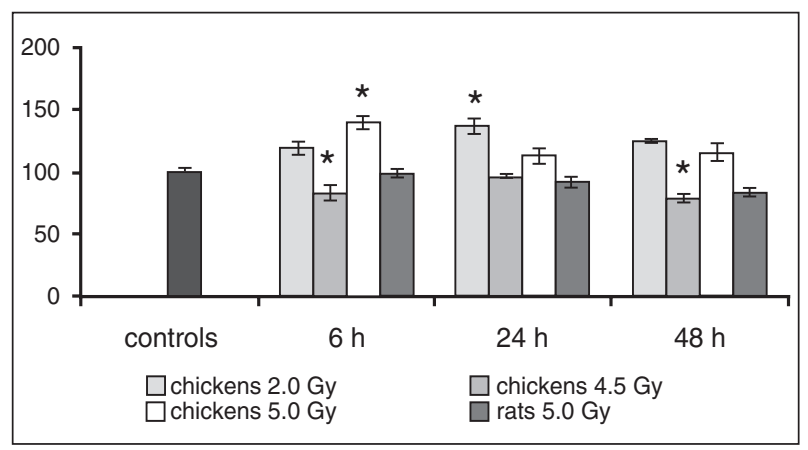

Fig. 2. Changes in the serum activity of AST (\%) after single whole-body irradiation. Significance of differences between irradiated and control groups is marked $*(p<0.05)$ The presented values are given against $100 \%$ level of the control values.

organisms related not only to changes in their cellular permeability and development of serious histological changes in hepatocytes early after irradiation but also to stimulation of de novo synthesis of transamination enzymes induced by increased secretion of the irradiated adrenal cortex.

When evaluating the changes that occur in the irradiated organism one must consider both external and internal factors that can affect the response to radiation (stress, species, age, sex). One of the factors may be the stress related to the handling of animals during irradiation. Therefore all control animals were exposed to the same handling procedures as the irradiated ones with the exception of irradiation with gamma rays.

The first symptoms of acute disease caused by irradiation include loss of appetite, nausea, vomiting and diarrhoea, i.e. symptoms associated with the gastrointestinal tract, i.e. the intestinal syndrome (Wisecup 1962). For this reason the animals were fasted overnight before the analysis. The differences in the activities of AST, observed after irradiation with doses of 4.5 Gy and 5.0 Gy, may be explained by different age of chickens.

Differences in the results obtained in broilers and laboratory rats exposed to the dose of 5.0 Gy may be ascribed to both differences in species and physiological-anatomical structure of the digestive system (Duke 1986). Differences in nitrogen metabolism between mammals 
and birds should also be considered. Uric acid is an important anti-oxidative metabolite and a scavenger of free radicals. Production of the complex of uric acid and iron inhibits considerably the oxidation of ascorbate and suppresses also peroxidation of lipids in liposomes and in the microsomal fraction of rat liver (Pechán 1995). The results obtained contribute to the knowledge in the field of radiobiology in general particularly with respect to chickens for which they present new and original information.

\section{Vplyv ionizujúceho žiarenia na aktivitu vybraných adaptívnych enzýmov}

Ciel’om predloženej práce bolo sledovanie účinku ionizujúceho žiarenia na aktivitu niektorých adaptívnych enzýmov $\mathrm{v}$ sére kura domáceho a laboratórnych potkanov.

Ožarovanie zvierat v upravených plexitových klietkach sme vykonali na Prírodovedeckej fakulte UPJŠ v Košiciach na prístroji CHISOSTAT ${ }^{60} \mathrm{Co}$-CHIRANA.

V experimente boli použitých 26 kurčiat vo veku 37 dní na začiatku experimentu a 45 kurčiat vo veku 28 dní na začiatku experimentu. Kurčatá podl'a použitej dávky sme rozdelili do 3 skupín. Prvú skupinu kurčiat vo veku 28 dní na začiatku experimentu sme ožiarili jednorázovou celotelovou dávkou 2,0 Gy gama lúčmi pri príkone $0,27 \mathrm{~Gy} / \mathrm{min}$. Druhú skupinu kurčiat vo veku 28 dní na začiatku experimentu sme ožiarili jednorázovou celotelovou dávkou 4,5 Gy pri príkone $0,33 \mathrm{~Gy} / \mathrm{min}$. Potkany a tretiu skupinu kurčiat vo veku 37 dní na začiatku experimentu sme ožiarili jednorázovou celotelovou dávkou 5,0 Gy gama lúčov pri príkone $0,27 \mathrm{~Gy} / \mathrm{min}$.

Zdanlivo boli ožarované kontroly, t.j. podrobili sa všetkým procedúram manipulácie ako ožarované s výnimkou samotného ožarovania gama lúčmi. Analýzy sme vykonali 6, 24 a 48 hodín po ožiarení.

Aktivita alanínaminotransferázy bola znížená vo všetkých sledovaných skupinách a obdobiach po ožiarení. U potkanov ožiarených dávkou 5,0 Gy bola aktivita ALT významne znížená 24 a 48 hodín po ožiarení v porovnaní s kontrolou. Aktivita aspartátaminotransferázy bola zvýšená vo všetkých sledovaných obdobiach u skupiny kurčiat ožiarených dávkou 2,0 Gy. U kurčiat ožiarených dávkou 4,5 Gy bola aktivita znížená, štatisticky významne 6 a 48 hodín po ožiarení. K zvýšeniu aktivity AST vo všetkých sledovaných obdobiach došlo u skupiny kurčiat ožiarených dávkou 5,0 Gy. Nevýznamne znížená bola aktivita AST vo všetkých sledovaných obdobiach po ožiarení v porovnanís kontrolou u potkanov ožiarených dávkou 5,0 Gy.

\section{References}

BUGARSKY, A, TAKÁČOVÁ, D, KORIM, P 1995: A ban on cruelty to animals - current legislation in SR (in Slovak) Slov vet časopis 20: 43.

CIGÁNKOVÁ, V, CIGÁNEK, J, TOMAJKOVÁ, E 1996: Post-irradiation morphological changes in the testes of sexually immature dogs. Folia Vet 40: 5-8

DUKE, GE 1986: Alimentary Canal: Anatomy, Regulation of Feeding, and Motility. In STURKIE, PD (editor): Avian Physiology. Springer-Verlag New York Berlin Heidelberg Tokyo. pp. 289-302

FEDOROČKO, P, BREZÁNI, P, MACKOVÁ, NO 1994: Radioprotection of mice by the bacterial extract Broncho - Vaxom ${ }^{\mathrm{R}}$ : haemopoietic stem cells and survival enhancement. Int J Radiat Biol 61: 511-518

FEDOROČKO, P, BREZÁNI, P, MACKOVÁ, NO 1994: Radioprotective effects of WR-2721, Broncho-Vaxom ${ }^{R}$ and their combinations: survival, myelopoietic restoration and induction of colony-stimulating activity in mice. Int J Immunopharmac 16: 177-184

FLORY,W, NEUHAUS, O W 1976: Induced transport of amino acids in rat liver after whole - body irradiation. Radiat Res 68: 138-147.

KALINA, I, KONEČNÁ, H, NÉMETHOVÁ, G, RAČEKOVÁ, N 1994: Adaptive response to ionizing radiation in normal and aneuploid human lymphocytes. Folia Biologica (Praha) 40: 119-123

KOTTFEROVÁ, J, KORÉNEKOVÁ, B, SIKLENKA, P, JACKOVÁ, A, HURNÁ, E, ŠÁLY, J 2001: The effect of $\mathrm{Cd}$ and vitamin $\mathrm{D}_{3}$ on the solidity of eggshell. Eur Food Res Technol 212: 153-155

KONEČNÁ, H, KALINA, I 1987: Dose-rate dependence of chromosome aberrations in human peripheral blood 
lymphocytes irradiated in vitro. Folia biologica (Praha) 33: 301-306

MARUYAMA, Y, FEOLA, JM 1987: Relative radiosensitivities of the thymus, spleen and lymphopoietic systems. Adv Radiat Biol 12: 1-82

ONDRAŠOVIČ, M, ONDRAŠOVIČOVÁ, O, VARGOVÁ, M, KOČIŠOVÁ, A 1997: Environmental problems in veterinary practice. UVM Kosice, $142 \mathrm{p}$.

PECHÁŇ, I 1995: Uric acid as an important antioxidative metabolite (In Slovak). Clin Biochem Metab, 3 (24): 207-210

SESZTÁKOVÁ, E, 1996: Post-radiation lesions in the peripheral blood of chickens (In Slovak). Infovet, 3-4, p. 61

STANÍKOVÁ, A, ARENDARČIK, J, MOLNÁROVÁ, M 1989: Changes in the hypothalamus and ependyma of the third ventricle of the brain sheep after irradiation and hormone stimulation. Acta Physiol Pol 40: 125-138

ŠEVČÍKOVÁ, Z, NAGYOVÁ, P, OJEDA, F, ŠKARDOVÁ, I, LEVKUT, M 2000: Medullar thymocyte structure and density in the chicken after experimental gamma irradiadion. Acta Vet Brno 69: 139-142

ŠKARDOVÁ, I, OJEDA, F, PROSBOVÁ, M, ROSIVAL, I 1994: Radiation induced disorders of hematopoesis in chicken (Apoptosis). Folia Vet 38: 81-84

TOROPILA, M 1993: Practical exercises in radiobiology. Magnus, Košice, 75p.

TOROPILA, M, AHLERS, I, AHLERSOVÁ, E, ĎATELINKA, I, BEŇOVÁ, K 1995: Effect of the low dose of continual gamma radiation on the changes activity of aspartate aminotransferase and alanine aminotransferase in liver and serum of the laboratory rats. Folia Vet 39: 29-32

TOROPILA, M, AHLERS, I, AHLERSOVÁ, E, ONDRAŠOVIČ, M, BEŇOVÁ, K, 1996: The influence of prolonged fasting on changes in the activity of selected adaptive enzymes in rat liver. Vet Med - Czech 41: 41-44

WISECUP, WG 1962: Fallout and livestock - some observations on the situation as appears today. J Am Vet Med Assoc 140: 236-240 